\title{
THE EFFECT OF PARTICLE SIZES ON METAL ACCUMULATION IN THE MARINE SEDIMENTS OF CAPE TOWN HARBOUR
}

\author{
HUSSEIN K. OKORO ${ }^{1 * 2}$, OLALEKAN S. FATOKI ${ }^{1}$, FOLAHAN A. ADEKOLA ${ }^{2}$, BHEKUMUSA J. XIMBA $^{1}$, \\ REINETTE G. SNYMAN ${ }^{3}$, AND BAXOLELE W. MDOKWANA ${ }^{1,4}$ \\ ${ }^{1}$ Environmental-Analytical Research Laboratory, Department of Chemistry, Faculty of Applied Science, \\ Cape Peninsula University of Technology, P.O. Box 1906, Cape Town 7535, South Africa, \\ *E-mail: Okoro.HK@unilorin.edu.ng; hkoadeola@gmail.com; okoroowo@yahoo.com \\ ${ }^{2}$ Environmental-Analytical Research Laboratory, Department of Chemistry, Faculty of Science, University of Ilorin, \\ P.M.B. 1515, Ilorin, Nigeria \\ ${ }^{3}$ Department of Biodiversity and Conservation Management, Faculty of Applied Sciences, Cape Peninsula University \\ of Technology P.O. Box 652, Cape Town 8000, South Africa \\ ${ }^{4}$ Department of Environmental Affairs, Ocean and Coastal branch, P.O. Box 52126, Victoria and Alfred Waterfront \\ Cape Town 8002, South Africa
}

\begin{abstract}
This study was carried out to assess the elemental concentration in sediment samples collected from six locations in the Cape Town Harbour. The effect of size variation was considered determinant on metals accumulated in sediments. An Inductively coupled plasma-Mass spectrometry (ICP-MS) instrument was used for the analysis. The following metals were investigated $\mathrm{Mn}, \mathrm{Cr}, \mathrm{V}, \mathrm{Ni}$, $\mathrm{Co}$, and As. The order of heavy metal concentration in sediments was $\mathrm{Mn}>\mathrm{Cr}>\mathrm{V}>\mathrm{Ni}>\mathrm{Co}>\mathrm{As}$. Strong correlation was found between these metals ( $\mathrm{Mn}$ and $\mathrm{V}$ in sizes $<75$ and $\geq 150$ ), (As and Co in size $\geq 150$ ), ( $\mathrm{Ni}$ and $\mathrm{Cr}$ in size $\geq 150$ and $<75$ ).
\end{abstract}

Key Words: Sediments; marine; harbor; modeling; correlation; residual plots; particle- size.

\section{INTRODUCTION}

One of the most important factors found, to date, about metal accumulation in sediment is size, this is mostly because it is usually related to weight. The specific surface area of sediments is independent on granulometric parameters and mineral composition. (Juraic, et al. 1980; Fatoki et al. 2012). Because of the increasing amounts of toxic metals from anthropogenic sources in the sedimentary environment. Various means have been devised for determining their effects on marine organisms. Fine particles have high specific areas that retain high amounts of metals (Wang et al. 2006). Also, small particles are often soluble and metals are more likely to traverse the gastric mucosa and be more easily absorbed in human tissues than for coarse fractions (Lin et al. 1998). It is generally believed that metals are associated with smaller grain-size particles (Martincic, et al., 1990). This trend is predominantly attributed to sorption, co-precipitation and complexing of metals on particle surfaces and coating. Smaller particle sizes have a larger surface to volume ratio and therefore contain higher concentration of metals. The specific surface area of sediments is independent on granulometric parameters and mineral composition (Juraic, et al., 1980). Because of the increasing amounts of toxic metals from anthropogenic sources in the sedimentary environment.
Various means have been devised for determining their effects on marine organisms.

The geochemical cycle of trace metals in the marine environment is determined by various mechanisms including the interaction of the metals with sediments. One of the most significant parameters influencing trace metal content in a sediment fraction is sediment size dimension. Therefore, a comparison of the contamination of the marine environment by anthropogenic trace metals in various geographic locations should be based on the standardization of several parameters, among them sediment size. Often analyses were conducted on a certain size fraction to correct natural variability (Solomons and Solomons 1980). However, Windom et al. (1989) considered that such a procedure can often lead to confusing results, since contaminant concentrations in a certain size fraction do not necessarily reflect its abundance in the total sediment. The generally accepted opinion is that the smaller the size of the sediment fraction, the larger the amount of trace metals bound to this fraction, and that trace elements are mainly present in the clay/silt particles with grain size less than $0.063 \mathrm{~mm}$ (Forstner et al. 1982). In general, this is because of the increase in specific surface area of the smaller fractions and to the surface properties of clay minerals (Forstner et al. 1982). 


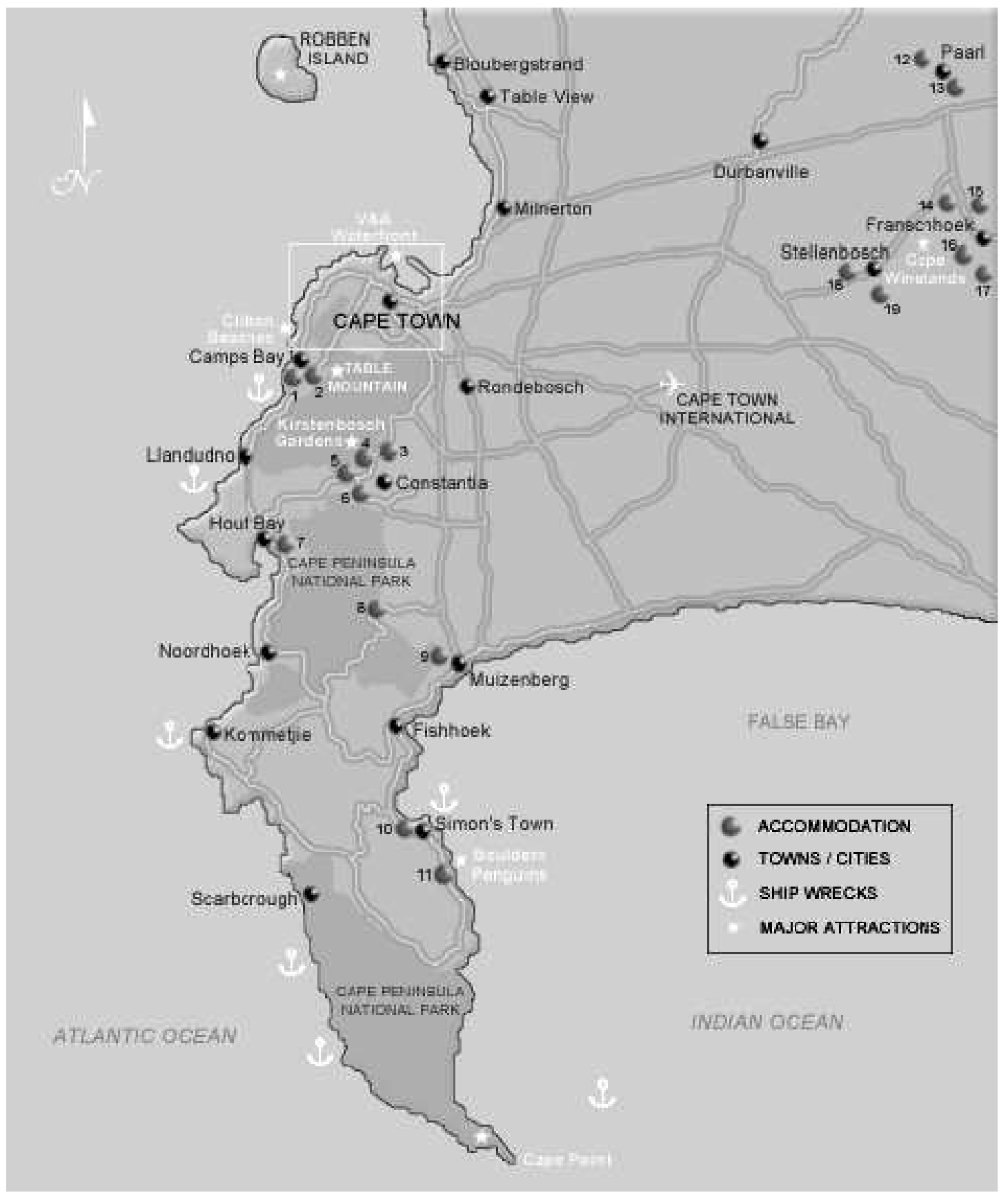

FIG. 1. Map indicating the sampling points and the position of Cape Town Harbour along the Atlantic Ocean and Indian Ocean.

Comparison of heavy metals distribution with grain size allows the identification of the area where the sediment fine fraction appears affected by heavy metal anthropogenic contamination (Leoni and Sartori 1996). Different results which reported that finer particles are associated with higher concentrations of heavy metals have, however, been reported by other investigators. The findings by Moore et al. 1989 and Combest (1991) demonstrated that metal concentrations did not increase with decreasing particle size, and the highest heavy metal concentrations were in the coarse silt and larger size fractions. Reaction to the uptake of metals has obvious, toxic and chronic responses. Levels of metals resulting in chronic responses are difficult to detect or assess. These levels are of importance, since prolonged chronic levels or synergistic effect of various metals and/ or other toxicants can result in undue stress on the organisms. The objective of this study is to evaluate the effect of particle size on the distribution of heavy metals in the Cape Town Harbour sediments. The total metal concentration was analyzed using inductively coupled plasma-Mass spectrometry (ICP-MS). 


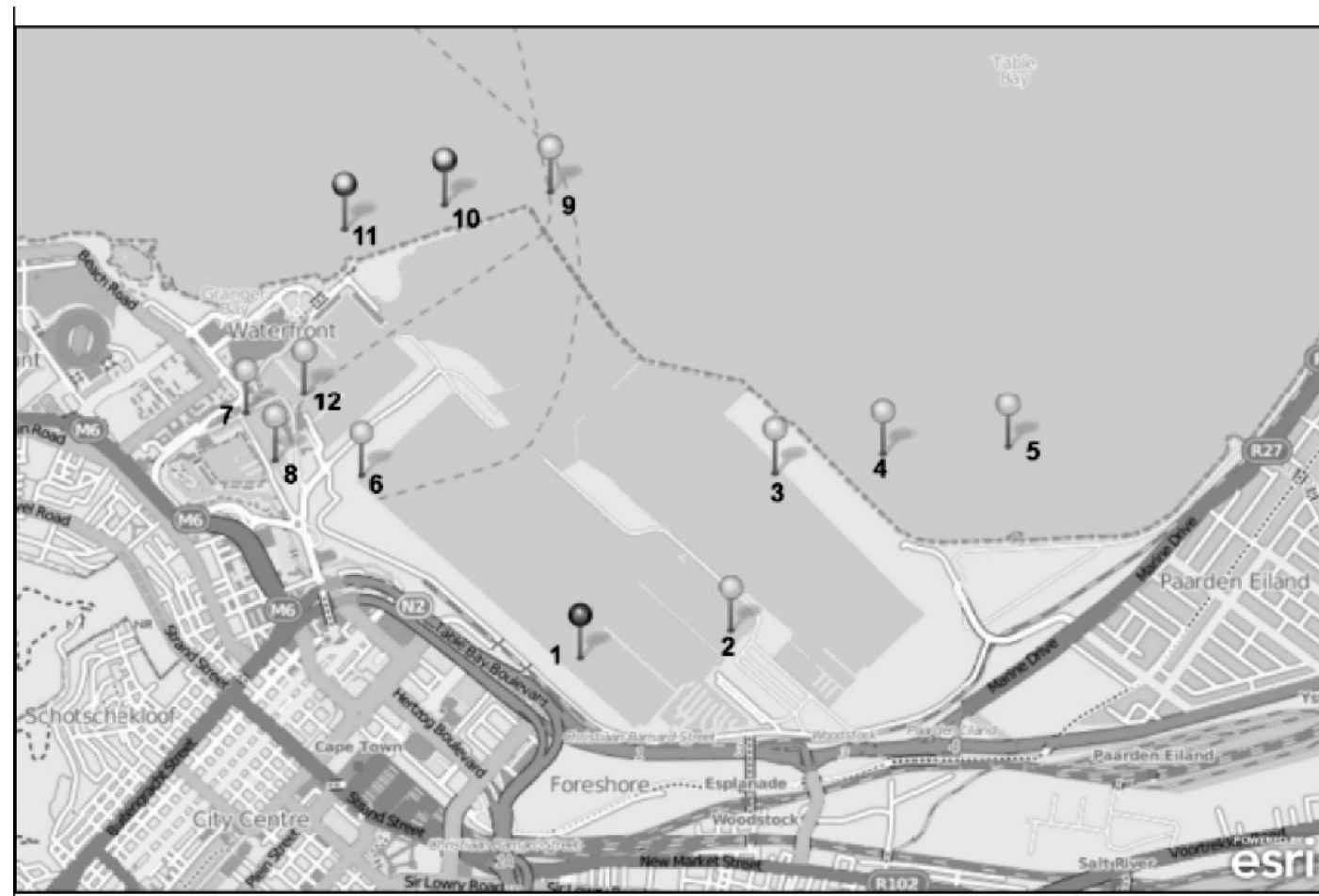

Map data (c) OpenStreetMap contributors, CC-BY-SA

Marine influence 2 Harbour points

Control points

FIG. 2. Map indicating the sampling points and the position of Cape Town Harbour along the Atlantic Ocean and Indian Ocean.

\section{MATERIALS AND METHODS}

\section{Study Area}

Cape Town competes with Alexandria harbour as the most famous port in Africa (Figs. 1 and 2). In fact, the harbour is one of the most beautiful harbours in the world that has a magnificent backdrop of Table Mountain framed by the mountainous Peninsula. The port is situated on one of the world's busiest trade routes and will always retain strategic and economic importance for that reason alone. Cape Town is also a busy container port, second in South Africa only to Durban, and handles the largest amount of fresh fruits. Fishing has a significant place in the economic activity of the port. The emerging oil industry in West Africa has also become a significant factor because one vessels visit the harbour for repair and maintenance facilities.

\section{Instrumentation}

Samples were analyzed with an Agilent 7,700 ICPMS. The Agilent 7,700 instrument used with a Meinhart nebulizer and silica cyclonic with continuous nebulisation. The operation parameters were: Plasma RF power: 1,550 W; sample depth: $8.0 \mathrm{~mm}$; Carrier gas: $1.08 \mathrm{~L} / \mathrm{min}$; Nebulizer pump: $0.10 \mathrm{rps}$; Helium gas: $5.3 \mathrm{~mL} / \mathrm{min}$.

\section{Sampling Procedure}

Six sampling stations were chosen for the sediment sampling (Fig. 2). Sediment samples were collected with the aid of sample Boat Waveride DTC 787C (6.3 m stringray cat hull) supplied by Stringray Marine was powered by Suzuki 90 hp's 4 stroke engines and equipped with Van Veen Grab sampler. A Garmin GPS was used to get the sampling coordinates. The sediment samples were placed in plastic poly Zip block bag in an ice chest and transported to the laboratory. Three replicates were taken from each station.

\section{Sample Preparation}

Sediment samples were dried in the oven overnight at $105^{\circ} \mathrm{C}$, until they were sufficiently dry to handle. A portion of each sample from the respective sampling sites was sieved

Table 1. Quality Control Assessment.

\begin{tabular}{cccc}
\hline Analytes & Certified Value & Measured Value & \% Recovery \\
\hline $\mathrm{V}$ & 9.67 & 9.33 & 96.48 \\
$\mathrm{Cr}$ & 9.73 & 9.67 & 99.43 \\
$\mathrm{Mn}$ & 9.67 & 9.25 & 95.61 \\
$\mathrm{Co}$ & 9.67 & 9.30 & 96.22 \\
$\mathrm{Ni}$ & 9.67 & 9.52 & 98.43 \\
$\mathrm{As}$ & 96.71 & 96.70 & 99.99 \\
\hline
\end{tabular}


Table 2. Physiochemical parameters measured in the sampling sites.

\begin{tabular}{lcccc}
\hline & & & \multicolumn{2}{c}{ Parameters } \\
\cline { 3 - 5 } \multicolumn{1}{c}{ Description } & Sampling Site & $\mathrm{pH}$ & Conductivity (mS) & TDS (ppm) \\
\hline Duncan Dock & 1 & 7.59 & 8.42 & 5,740 \\
Duncan Dock & 2 & 7.1 & 2.4 & 2,710 \\
Inside Sea 500 m away from Point 4 & 3 & 7.5 & 3.19 & 2,160 \\
Duncan Dock & 4 & 7.25 & 8.32 & 5,680 \\
Robinson DRY Dock & 5 & 7.86 & 2.07 & 1,420 \\
Synchrolift & 6 & 7.77 & 7.85 & 5,330 \\
\hline
\end{tabular}

into 3 sub-samples with grain-sizes of $<75, \geq 75$ and $\geq 150$ micro-meters. This was performed by a dry sieving method, using a mechanical shaker sieve set. For the analysis of the sediment physico-chemical parameter, $10 \mathrm{~g}$ of dried sediment was mixed with $50 \mathrm{ml}$ of distilled water and the $\mathrm{pH}$, conductivity and total dissolved solids (TDS) were determined. A triplicate 0.5 - g sediment sample was digested with aqua-regia ( $7.5 \mathrm{ml} \mathrm{HCL}$ and $2.5 \mathrm{ml} \mathrm{HNO}_{3}$ ) in a microwave unit and heated using the following heating program:
$250 \mathrm{~W}$ for $6 \mathrm{~min}, 400 \mathrm{~W}$ for $6 \mathrm{~min}, 600 \mathrm{~W}$ for $6 \mathrm{~min}$ and the vent time used was $5 \mathrm{~min}$ and the total digestion process was $24 \mathrm{~min}$. The digested residues were filtered to get a clear solution of which $10 \mathrm{ml}$ was then diluted to $100 \mathrm{ml}$ using Milli Q water. The obtained solutions were analyzed for the following metals: $\mathrm{Mn}, \mathrm{Cr}, \mathrm{V}, \mathrm{Ni}, \mathrm{Co}$ and As by ICP-MS. The measurements were programmed and adjusted to analyze the samples in triplicates while blank samples were analyzed after 10 measurements.
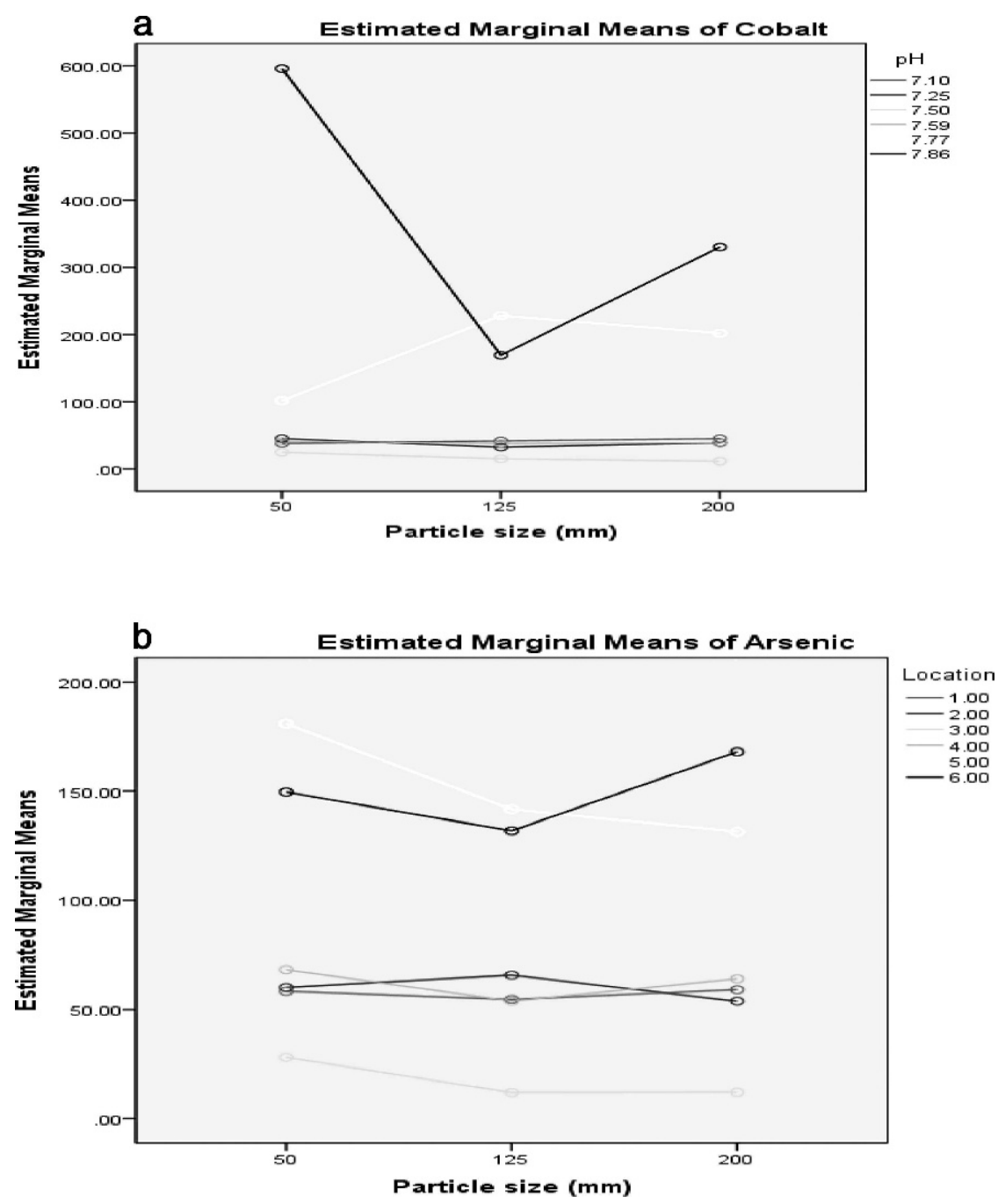

FIG. 3a. Variation of particle size with $\mathrm{pH}$.

FIG. 3b. Variation of particle $\mathrm{pH}$ with particle sizes. 
Table 3. Concentrations of some selected heavy metals in different size fractions in sediments of the Cape Town Harbour.

\begin{tabular}{|c|c|c|c|c|c|c|c|}
\hline & & \multicolumn{6}{|c|}{ Heavy metal concentration in $\mathrm{ppb}(\mu \mathrm{g} / \mathrm{g})$} \\
\hline \multicolumn{2}{|c|}{ Sample } & Vanadium & Chromium & Manganese & Cobalt & Nickel & Arsenic \\
\hline Location & Grain size & Mean $\pm \mathrm{SE}$ & Mean \pm SE & Mean \pm SE & Mean $\pm \mathrm{SE}$ & Mean $\pm \mathrm{SE}$ & Mean \pm SE \\
\hline 1 & $\begin{array}{r}<75 \\
\geq 75 \\
\geq 150\end{array}$ & $\begin{array}{r}233.78 \pm 2.19 \\
183 \pm 2.19 \\
219 \pm 1.17\end{array}$ & $\begin{array}{l}371 \pm 8.32 \\
362 \pm 2.39 \\
365 \pm 7.18\end{array}$ & $\begin{array}{r}1,176 \pm 4.62 \\
951 \pm 4.97 \\
1,087 \pm 1.09\end{array}$ & $\begin{array}{l}41 \pm 0.68 \\
38 \pm 0.19 \\
39 \pm 0.38\end{array}$ & $\begin{array}{l}149 \pm 1.69 \\
142 \pm 2.15 \\
136 \pm 0.76\end{array}$ & $\begin{array}{l}58 \pm 0.66 \\
54 \pm 0.58 \\
59 \pm 0.76\end{array}$ \\
\hline 2 & $\begin{array}{r}<75 \\
\geq 75 \\
\geq 150\end{array}$ & $\begin{array}{l}202 \pm 4.99 \\
224 \pm 2.49 \\
189 \pm 2.49\end{array}$ & $\begin{array}{l}323 \pm 4.97 \\
409 \pm 6.36 \\
324 \pm 5.85\end{array}$ & $\begin{array}{r}888 \pm 2.72 \\
1,075 \pm 2.29 \\
774 \pm 1.59\end{array}$ & $\begin{array}{l}38 \pm 0.76 \\
42 \pm 0.52 \\
45 \pm 0.74\end{array}$ & $\begin{array}{l}127 \pm 2.84 \\
140 \pm 2.36 \\
114 \pm 1.46\end{array}$ & $\begin{array}{l}60 \pm 0.97 \\
66 \pm 0.48 \\
54 \pm 0.74\end{array}$ \\
\hline 3 & $\begin{array}{r}<75 \\
\geq 75 \\
\geq 150\end{array}$ & $\begin{array}{l}84 \pm 0.70 \\
50 \pm 0.39 \\
46 \pm 0.49\end{array}$ & $\begin{array}{l}290 \pm 6.86 \\
178 \pm 3.97 \\
191 \pm 2.99\end{array}$ & $\begin{array}{l}584 \pm 3.88 \\
313 \pm 1.94 \\
306 \pm 1.34\end{array}$ & $\begin{array}{l}25 \pm 0.23 \\
15 \pm 0.54 \\
11 \pm 0.07\end{array}$ & $\begin{array}{r}134 \pm 1.57 \\
58 \pm 0.81 \\
58 \pm 0.30\end{array}$ & $\begin{array}{l}28 \pm 0.18 \\
12 \pm 0.11 \\
12 \pm 0.19\end{array}$ \\
\hline 4 & $\begin{array}{r}<75 \\
\geq 75 \\
\geq 150\end{array}$ & $\begin{array}{l}217 \pm 2.27 \\
175 \pm 3.44 \\
234 \pm 3.42\end{array}$ & $\begin{array}{l}327 \pm 5.44 \\
277 \pm 3.45 \\
336 \pm 2.46\end{array}$ & $\begin{array}{l}1,579 \pm 4.18 \\
1,108 \pm 8.01 \\
1,407 \pm 1.79\end{array}$ & $\begin{array}{l}45 \pm 0.41 \\
33 \pm 1.76 \\
39 \pm 0.64\end{array}$ & $\begin{array}{l}142 \pm 1.44 \\
114 \pm 2.10 \\
130 \pm 0.89\end{array}$ & $\begin{array}{l}68 \pm 0.66 \\
54 \pm 0.90 \\
64 \pm 0.83\end{array}$ \\
\hline 5 & $\begin{array}{r}<75 \\
\geq 75 \\
\geq 150\end{array}$ & $\begin{array}{l}285 \pm 2.29 \\
267 \pm 2.19 \\
248 \pm 3.76\end{array}$ & $\begin{array}{l}547 \pm 1.33 \\
709 \pm 6.05 \\
938 \pm 6.41\end{array}$ & $\begin{array}{l}1,038 \pm 2.26 \\
1,026 \pm 6.12 \\
1,108 \pm 2.20\end{array}$ & $\begin{array}{l}594 \pm 4.67 \\
163 \pm 5.72 \\
330 \pm 4.70\end{array}$ & $\begin{array}{l}189 \pm 1.33 \\
240 \pm 2.20 \\
289 \pm 4.58\end{array}$ & $\begin{array}{l}181 \pm 2.07 \\
142 \pm 1.25 \\
131 \pm 2.37\end{array}$ \\
\hline 6 & $\begin{array}{r}<75 \\
\geq 75 \\
\geq 150\end{array}$ & $\begin{array}{l}314 \pm 5.86 \\
187 \pm 1.34 \\
320 \pm 1.78\end{array}$ & $\begin{array}{r}693 \pm 0.40 \\
927 \pm 8.01 \\
1,214 \pm 7.93\end{array}$ & $\begin{array}{l}1,092 \pm 2.89 \\
1,111 \pm 2.32 \\
1,200 \pm 1.94\end{array}$ & $\begin{array}{l}102 \pm 1.54 \\
228 \pm 0.14 \\
202 \pm 4.29\end{array}$ & $\begin{array}{l}282 \pm 2.98 \\
542 \pm 5.93 \\
521 \pm 3.73\end{array}$ & $\begin{array}{l}150 \pm 1.61 \\
132 \pm 0.96 \\
168 \pm 1.15\end{array}$ \\
\hline
\end{tabular}

\section{Quality Assurance}

For quantification of the element of interest, the ICPMS were calibrated daily using NIST traceable standards. A quality control standard was analyzed prior to the samples to verify the accuracy of the calibration standards, while control standards were used throughout the analysis to monitor accuracy and instrument drift. Internal standards for ICP-MS were introduced continuously with the samples along with standards to correct for drift because of high matrix load. Data acquisition and processing was software controlled and exported in Excel format.

\section{Statistical Analyses}

The results were statistically analysed using SAS 9 software (Cary, NC, U.S.). Pearson's correlation was applied to evaluate the relationships between the variables and a correlation coefficient with $\mathrm{p} \leq 0.05$, regarded as significant. Principal Component Analysis (PCA), used to analyse the data.

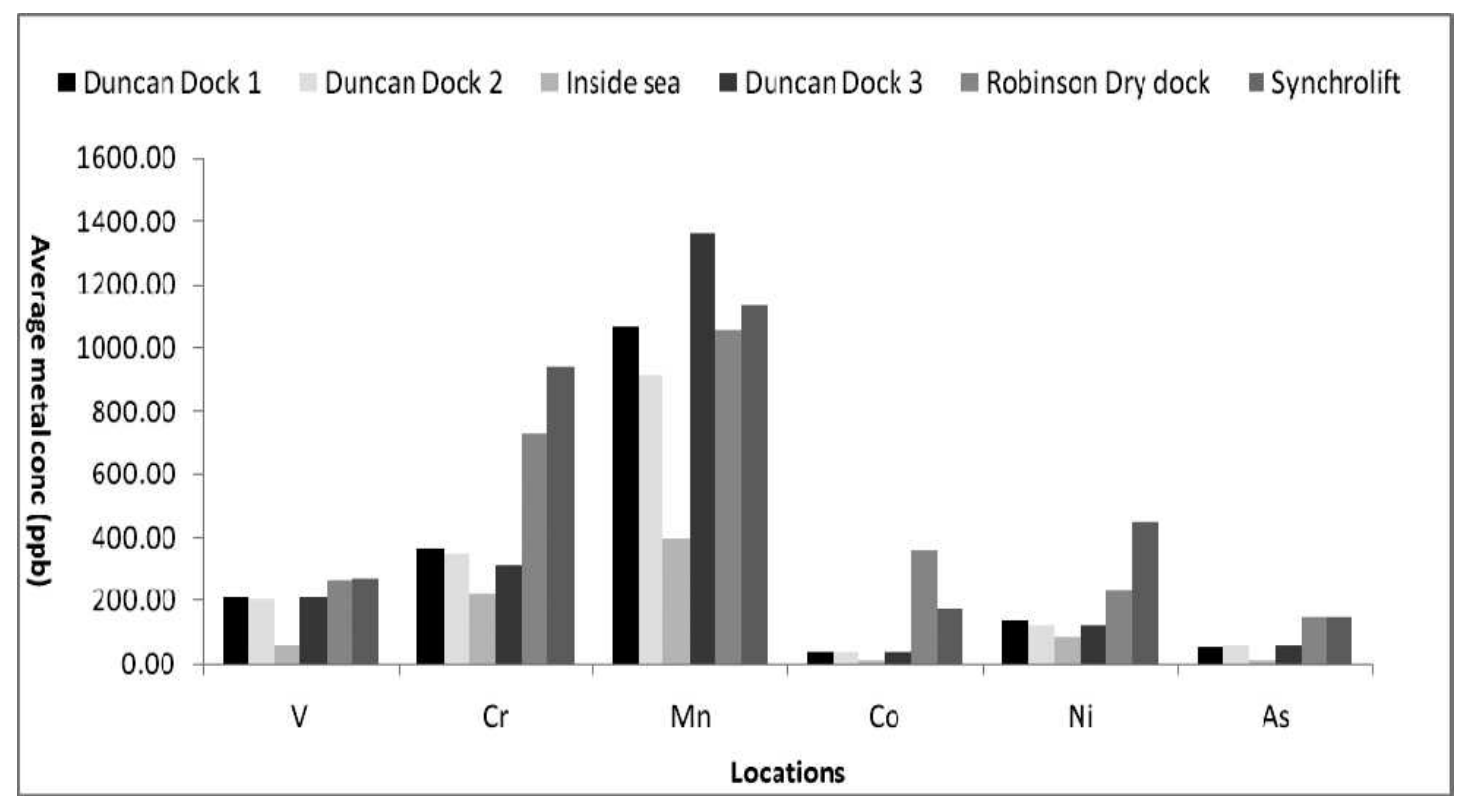

FIG. 4. Average metal concentration across locations. 


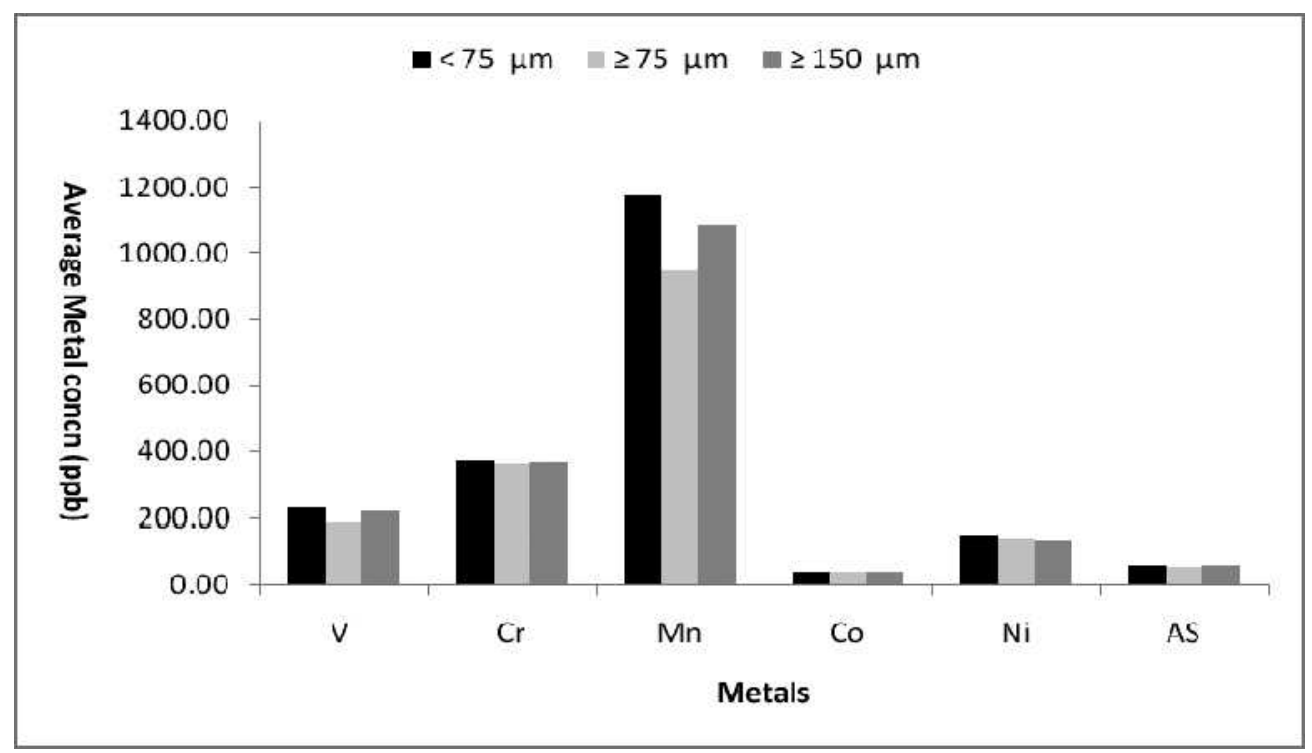

FIG. 5. Average metal concentration in selected grain sizes in location 1.

Result and Discussion

Heavy metal percent recoveries from a sediment certified standard reference material were calculated for all the metals. The high percentage recoveries ranged from 95.61 to $99.99 \%$. This was within acceptable limits for all elements examined and showed the accuracy of the digestion procedure (Table 1).

\section{Physicochemical Characteristics of the Sediments}

The sediment $\mathrm{pH}$ ranged from 7.10 to 7.86 . Sediment samples located close to the estuary were more alkaline, because of infusion of salt water from the sea during high tide and may also be because of the presence of carbonates of calcium and magnesium (Table 2, Fig. 3a, b) and the relationship between the $\mathrm{pH}$ and the particle sizes for each metal investigated.

Assume that the power relation of Wang and Fisher (1997) that body weights to metal bioaccumulation will also hold for body size versus accumulation

$$
\begin{aligned}
\mathrm{BCF} & =\mathrm{aw}^{\mathrm{b}} \\
\operatorname{Let} \mathrm{S} & =\mathrm{BCF}=\mathrm{aw}^{\mathrm{b}} \\
\log (\mathrm{S}) & =\log (\mathrm{a})+\mathrm{b} \log (\mathrm{W})
\end{aligned}
$$

$\mathrm{b}$ can be calculated from the above equation as the slope of the Log-log relationship between the BCF (Bioconcentration factor) and $\mathrm{W}$ (dry weight). Plotting $\mathrm{S}$

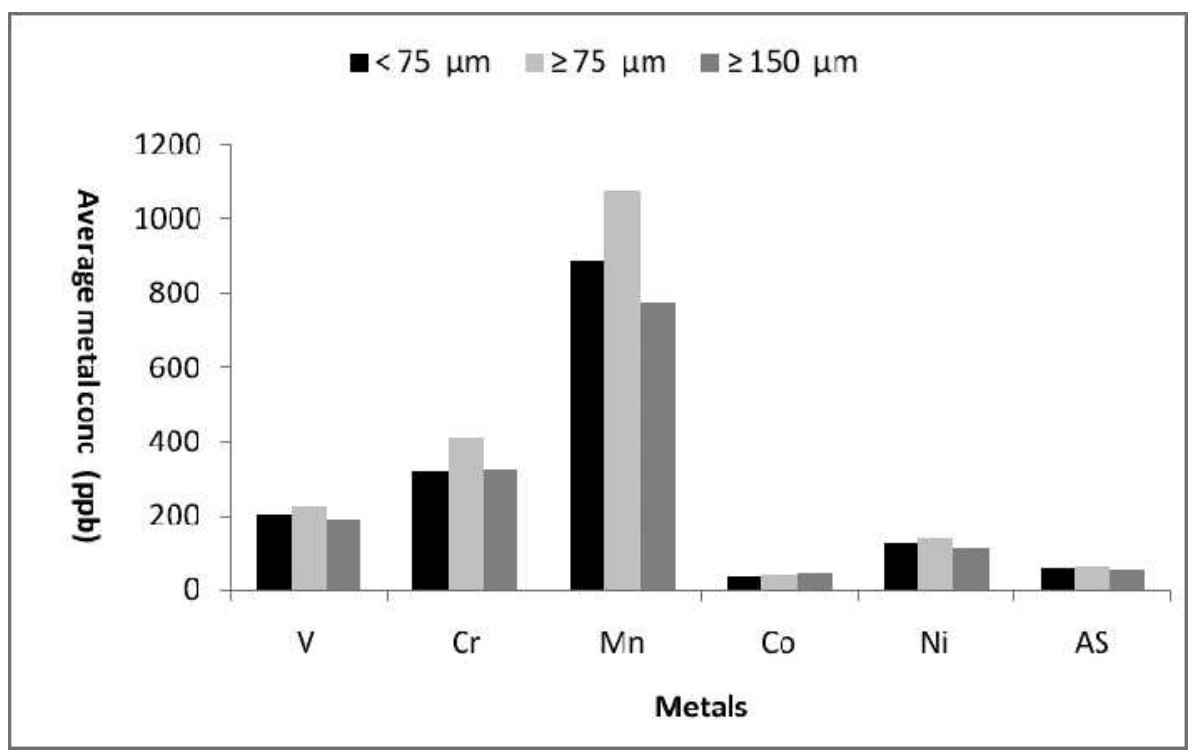

FIG. 6. Average metal concentration in selected grain sizes in location 2. 


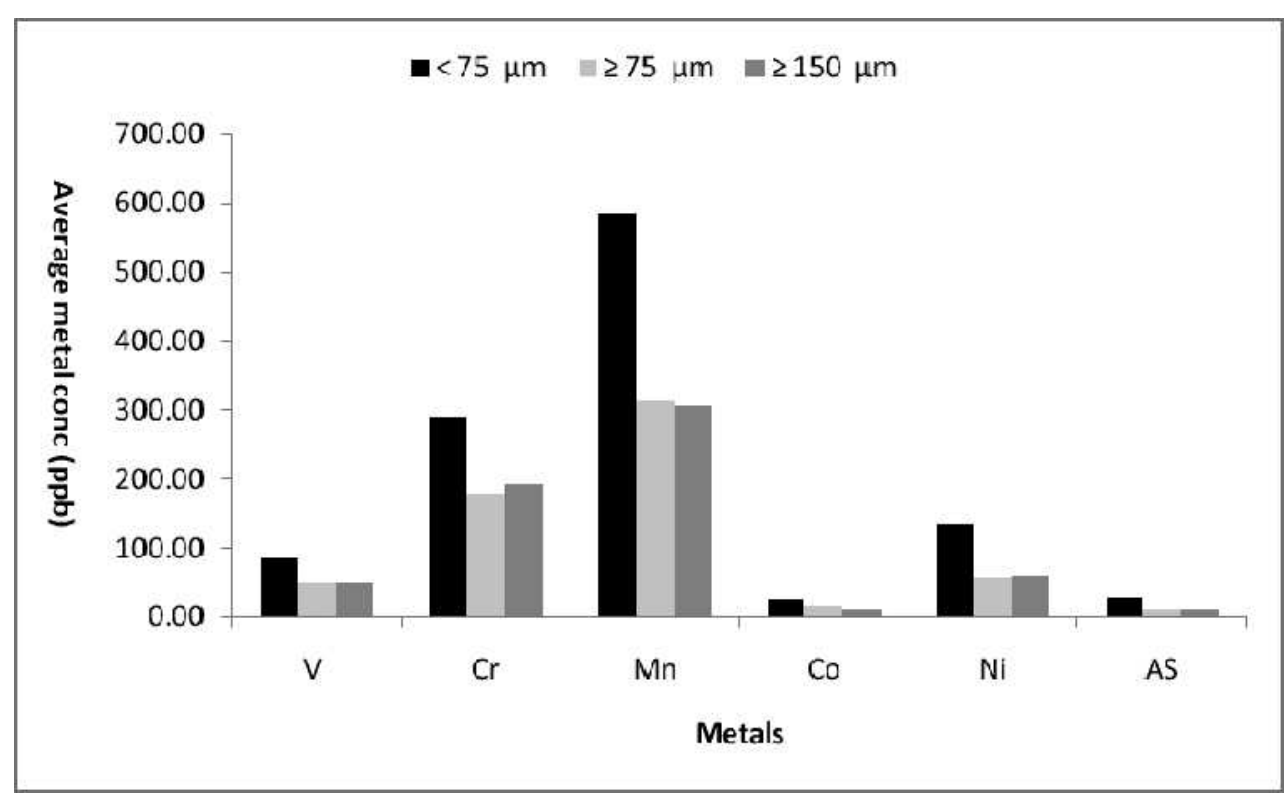

FIG. 7. Average metal concentration in selected grain sizes in location 3.

(Bioconcentration factor) versus average size show how they vary with $\mathrm{pH}$ on $\log \log$ graph (Fig. 3a-3f), for $\mathrm{b}$ value $>0$ the metal accumulation increases with size (+ve), while a $\mathrm{b}$ value $<0$ the metal accumulation decreases with size $(-v e)$, and when the $b$ value is close to 0 , this indicates that the metal accumulation is relatively independent of particle size The sediment conductivity ranged from 2.07 to $8.42 \mathrm{mS}$ and the total dissolved solutes ranged from 1,420 to $5,740 \mathrm{ppm}$. The highest conductivity and TDS values (Table 2) were found in locations 1, 4 and 6, this may be attributed to various industrial activities taking place in these locations. Many studies have been carried out on heavy metal distribution, and some authors have shown the effect of particle size on heavy metal distribution and have indicated that concentrations of metals in sediments increase with decreasing particle size. Chromium concentration in this study ranged from 219.8 to 944 $\mathrm{ppb}$, with the lowest chromium concentration recorded in location 3 and the highest being in location 6 (Table 3). This high Cr concentration may be attributed to ship repairs and other industrial activities taking place at this location. Ni concentration ranged from 83.71 to $448.3 \mathrm{ppb}$, with the lowest $\mathrm{Ni}$ concentration being location 3 and the highest being location 6 . This is because the municipal wastewater as this is the water

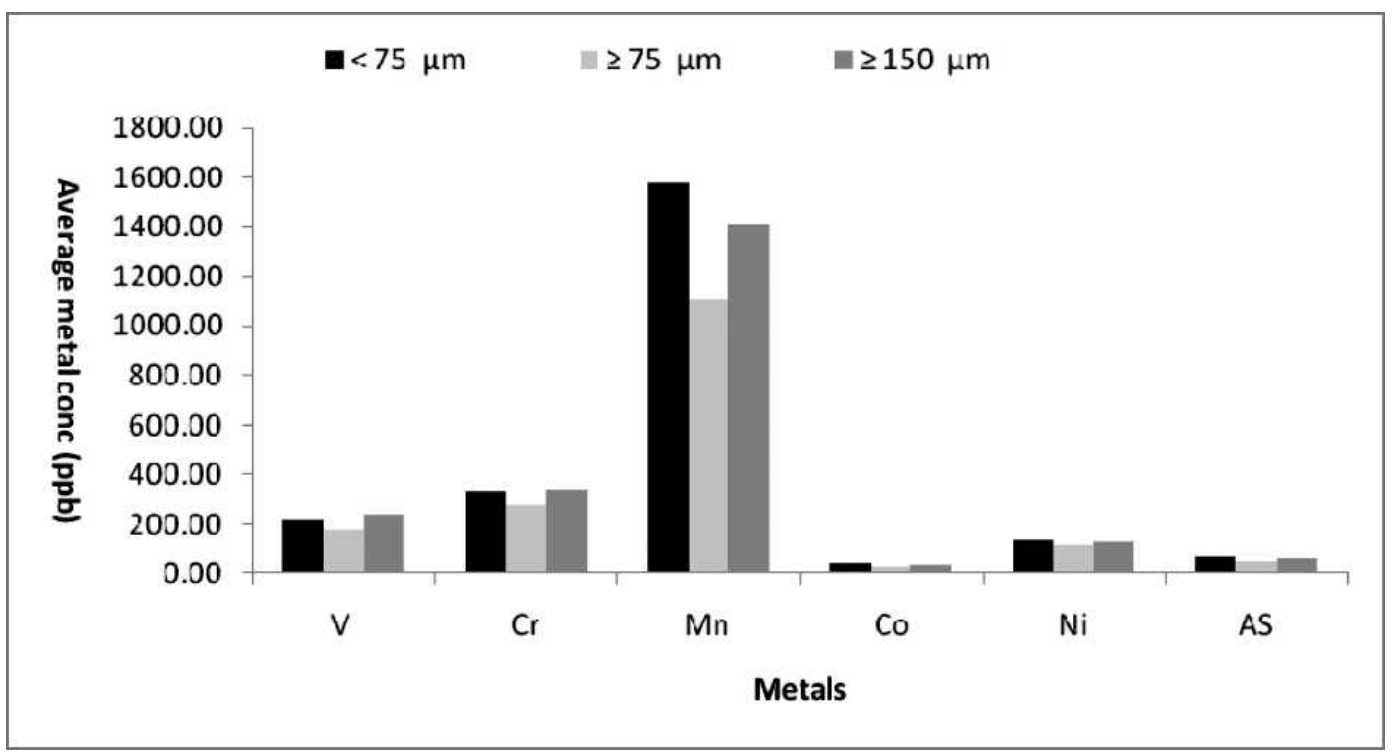

FIG. 8. Average metal concentration in selected grain sizes in location 4 . 


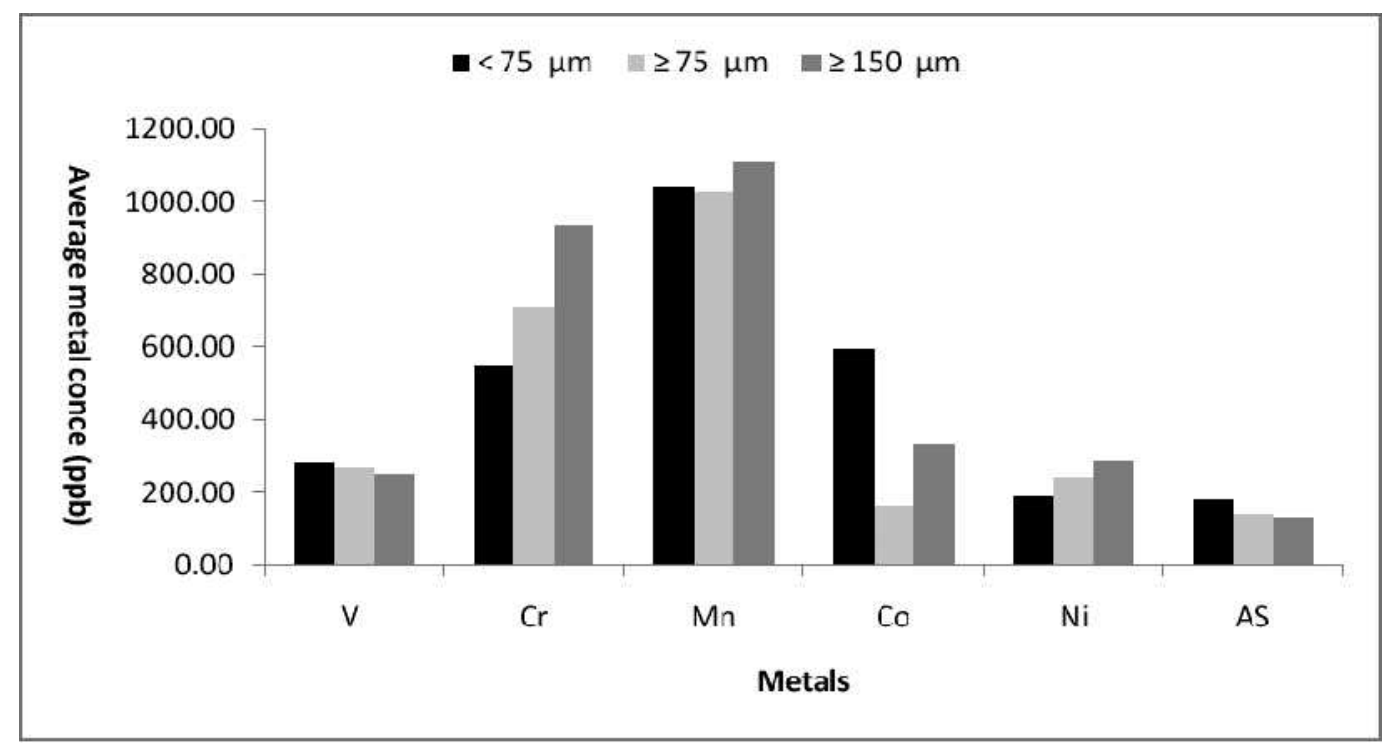

FIG. 9. Average metal concentration in selected grain sizes in location 5.

from sewage treatment plants. Vanadium concentration ranged from 60.3 to $274 \mathrm{ppb}$, the lowest $\mathrm{V}$ concentration being location 3 and the highest being in location 6 . Vanadium contamination of soil may occur whenever petroleum or coal bi-products are accidentally discharged into the sediment environment.

Mn concentration ranged from 401.1 to $1,364 \mathrm{ppb}$, with the lowest $\mathrm{Mn}$ concentration being location 3 and the highest location 6 . This may be attributed to shipments because potassium permanganate is a potent oxidizer and is used as disinfectant. Co concentration ranged from 17.12 to $362.3 \mathrm{ppb}$, the lowest Co concentration was recorded in location 3 and the highest being location 5 . This may be because of the painting of ships, because cobalt is used as a dying agent for paints. Arsenic concentration ranged 17.33 to $151.3 \mathrm{ppb}$, with the lowest As concentration being location 3 and the highest being location 5 , this may be attributed to the lead and zinc production used in agriculture. Highest concentrations of these elements were found in the areas that experience intense traffic conditions. The Major "hot-spot" included Site 6 at Cape Town Harbour (grossly contaminated with $\mathrm{Cr}$, Co and $\mathrm{Ni}$ ). The least contaminated site was location 3. This was expected because this location was inside the sea. The order of heavy metal concentration in sediments was $\mathrm{Mn}>\mathrm{Cr}>$ $\mathrm{V}>\mathrm{Ni}>\mathrm{Co}>\mathrm{As}$. The presence of elevated levels of $\mathrm{Mn}$ and $\mathrm{Cr}$ in almost all locations (Fig. 4) and the

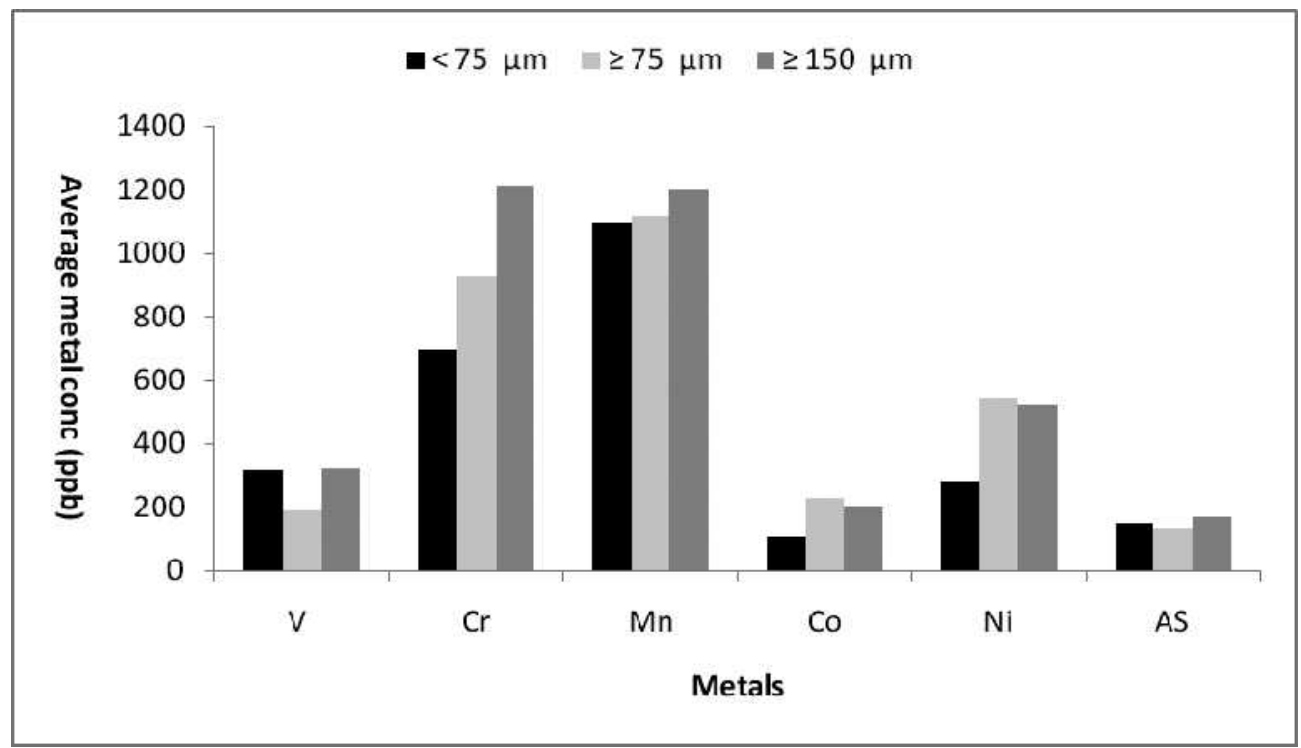

FIG. 10. Average metal concentration in selected grain sizes in location 6 . 


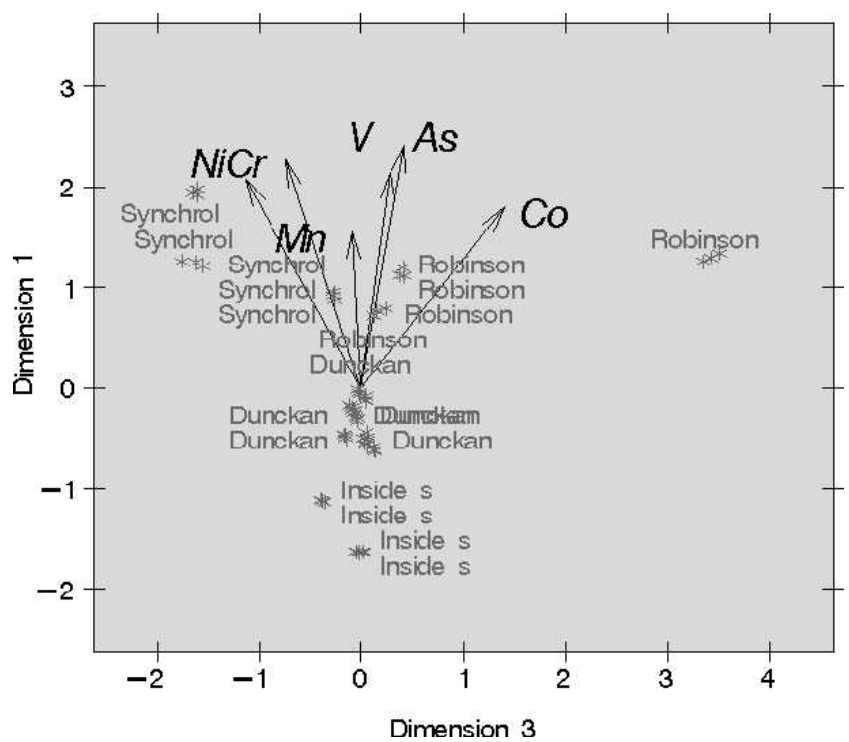

FIG. 11. PCA showing distribution of the metals across locations.

increases potential for human exposure to heavy metals are serious matters of concern.

It is generally believed that metals are associated with smaller grain-size particles, (Whitney 1975; Gibbs 1977 and Martincic et al., 1990). This trend (Figs. 5-10) is followed by all analytes in location 1 except $\mathrm{Mn}$. In location 5 this trend is followed by V, Co and As while chromium, manganese, and nickel reveal the opposite. This trend in location 6 is not followed by any element. This trend in location 5 is only followed by chromium and nickel, while vanadium, arsenic reveals the opposite and manganese and cobalt showing no trend. In location 6 , this trend is only followed by chromium and manganese, while other elements reveal no trend as shown in Figs. 5-10.

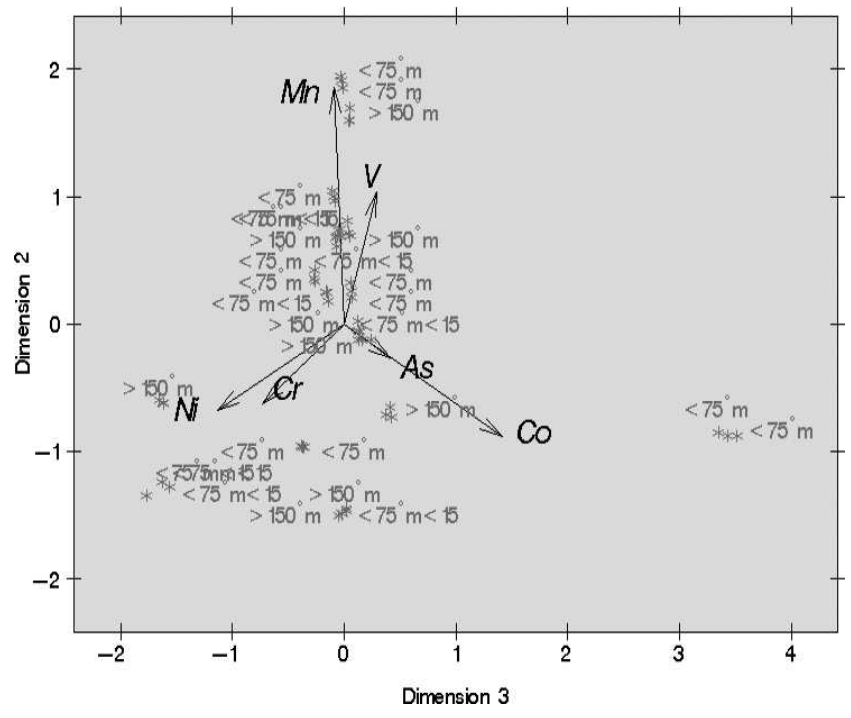

FIG. 12. PCA showing distribution of the metals in different sizes.

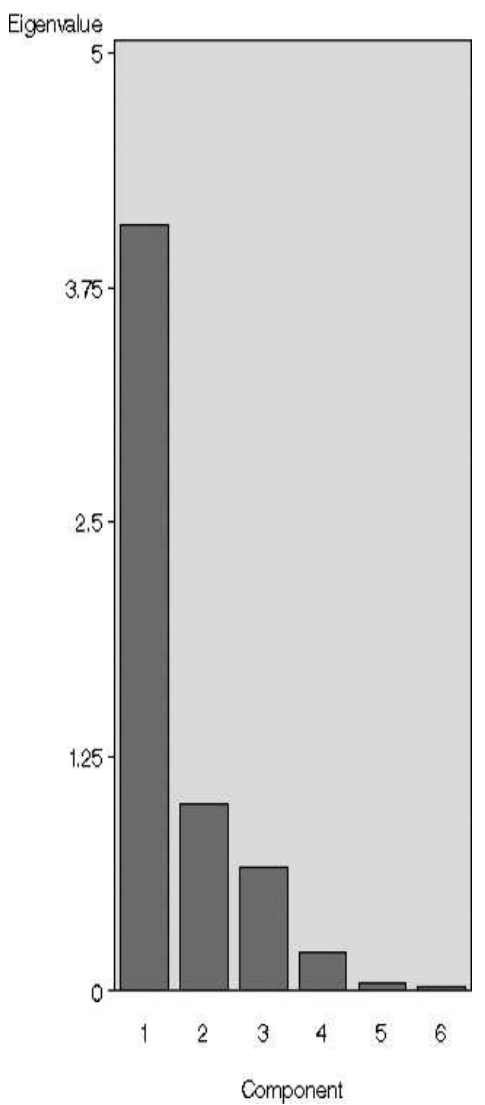

FIG. 13. graph of Eigen value vs. Component.

\section{Stastical Analysis}

The PCA as shown in Figs. 11 and 12 was used to group the elements according to how they accumulate in different locations and sizes. Strong correlation was found between these metals ( $\mathrm{Mn}$ and $\mathrm{V}$ in sizes $<75$ and $\geq 150$ ), (As and $\mathrm{Co}$ in size $\geq 150$ ), ( $\mathrm{Ni}$ and $\mathrm{Cr}$ in size $\geq 150$ and $<75$ ) respectively. The strong correlation that was found confirmed that their contribution was from anthropogenic sources, i.e., industrial activities, storm and urban inflow, agricultural activities, and ship reparation that occur within and around the harbour. Component variations in heavy metal from eigenvalues are shown in Fig. 13. The eigenvalues decrease in this order $\mathrm{Mn}>\mathrm{Cr}>\mathrm{V}>\mathrm{Ni}>\mathrm{Co}>$ As respectively. $\mathrm{Ni}, \mathrm{Co}$ and As have very low eigenvalues. They can be said to be of natural origin while $\mathrm{Mn}, \mathrm{Cr}$ and $\mathrm{V}$ are of anthropogenic sources because of their high level of component variation.

Pearson correlation coefficients for heavy metals in sediments collected from Cape Town Harbour is presented in Table 4. High correlation coefficients $(r>$ 0.8 ) were calculated between ( $\mathrm{V}$ and $\mathrm{As})$; ( $\mathrm{Cr}$ and $\mathrm{Ni}$ ); ( $\mathrm{Cr}$ and $\mathrm{As}$ ) and (Co and As) respectively.

Plot of the residuals versus predicted Y (Fig. 14). The pattern shown indicates no problems because of the assumption that the residuals are normally distributed 
Table 4. Pearson correlation coefficients between metal levels in sediment by ICP-MS.

\begin{tabular}{|c|c|c|c|c|c|c|}
\hline & $\mathrm{V}$ & $\mathrm{Cr}$ & $\mathrm{Mn}$ & $\mathrm{Co}$ & $\mathrm{Ni}$ & As \\
\hline \multirow[t]{2}{*}{ V } & 1.00000 & 0.64936 & 0.76416 & 0.48935 & 0.51652 & 0.82518 \\
\hline & & $<0.0001$ & $<0.0001$ & 0.0002 & $<0.0001$ & $<0.0001$ \\
\hline \multirow[t]{2}{*}{$\mathrm{Cr}$} & & 1.00000 & 0.37634 & 0.57221 & 0.93182 & 0.84624 \\
\hline & & & 0.0050 & $<0.0001$ & $<0.0001$ & $<0.0001$ \\
\hline \multirow[t]{2}{*}{ Mn } & & & 1.00000 & 0.20873 & 0.36098 & 0.48503 \\
\hline & & & & 0.1298 & 0.0073 & 0.0002 \\
\hline \multirow[t]{2}{*}{ Co } & & & & 1.00000 & 0.45953 & 0.80127 \\
\hline & & & & & 0.0005 & $<0.0001$ \\
\hline \multirow[t]{2}{*}{$\mathrm{Ni}$} & & & & & 1.00000 & 0.74655 \\
\hline & & & & & & $<0.0001$ \\
\hline As & & & & & & 1.00000 \\
\hline
\end{tabular}

KEY: Upper value $=$ correlation coefficient $r$.

Lower value $=$ Significance level $\mathrm{p} \leq 0.05$.

at each level of Y and constant in variance across levels of Y. SPSS does not automatically draw in the regression line (the horizontal line at residual $=0$ ). A similar trend was observed for all the metals as shown in Fig. 14 for Arsenic. There is no variation for the residual plots drawn for each metals proving that the mean is closer to the residual and the data were in alignment.

\section{CONCLUSION}

The metal data for different size particles of the sediment samples collected from the different locations along the Cape Town Harbour suggested that the distribution of heavy metals in sediments had no obvious trend in terms of heavy metal concentration. Highest concentrations of these elements were found in the areas that experience intense traffic conditions. The

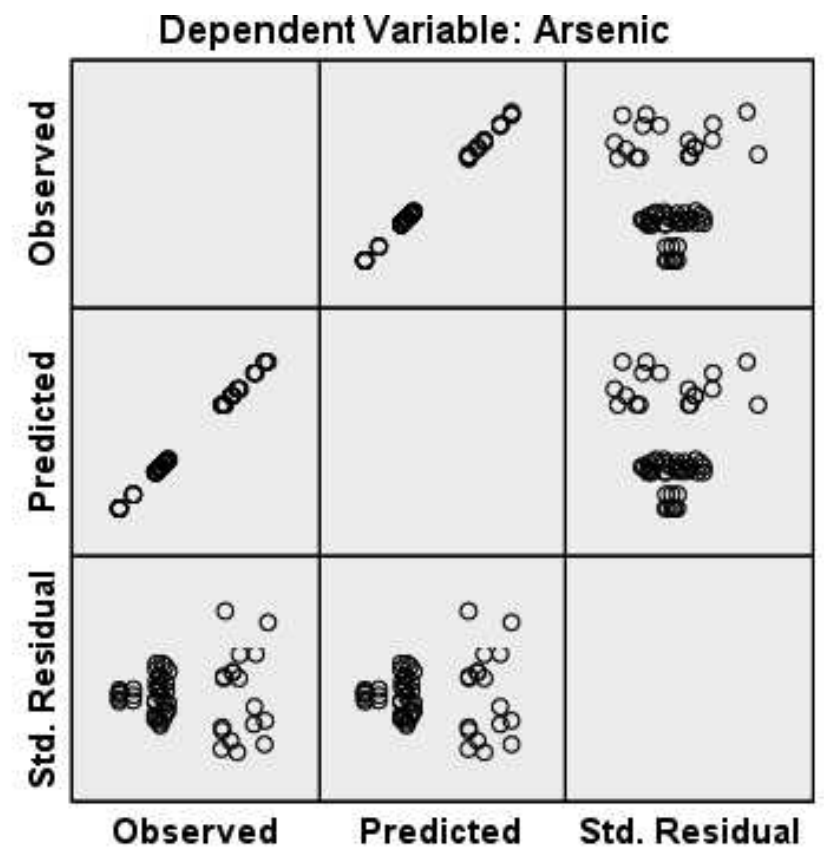

Model: Intercept $+\mathrm{pH}+$ Conductivity $+\mathrm{TDS}+\mathrm{Part}$ size + Location $+\mathrm{pH}$ * Conductivity $+\mathrm{pH}$ * TDS + $\mathrm{pH}^{*}$ Part_size $+\mathrm{pH}^{*}$ Location + Conductivity * TDS + Conductivity * Part_size + Conductivity * Location + TDS *Part_size + TDS * Location + Part_size * Lccation $+\mathrm{pH}^{*}$ Conductivity * TDS + $\mathrm{pH}^{*}$ Conductivity *

Part_size $+\mathrm{pH}^{*}$ Conductivity * Location $+\mathrm{pH}^{*}{ }^{-} \mathrm{DS}$ * Part size $+\mathrm{pH}{ }^{*}$ TDS * Location $+\mathrm{pH}$ * Part_size * Location + Conductivity * TDS * Part_size + Conductivity * TDS * Location + Conductivity * Part_Size * Location + TDS * Part_size * Location $+\mathrm{pH}^{*}{ }^{*}$ Conductivity ${ }^{*}$ TDS * Part_size $+\mathrm{pH}^{*}$ Conductivity ${ }^{*}$ TDS $^{*}$ Location $+\mathrm{pH}^{*}$ Conductivity * Part_size * Location $+\mathrm{pH}^{*}{ }^{*} \mathrm{TDS}^{*}$ Part size * Location + Conductivity * TDS * Part_size * Locätion $+\mathrm{pH}^{*}$ Conductivity * TDS * Part_size * Location

FIG. 14. A representative Observed $*$ Predicted $*$ Std. Residual Plots. 
major "hot-spot" included Site 6 (Synchrolift) at Cape Town Harbour (grossly contaminated with $\mathrm{Sn}, \mathrm{Cr}, \mathrm{Co}$ and Ni). The least contaminated was location 3. This was expected as this location was inside the sea. The order of heavy metal concentration in sediments was $\mathrm{Mn}>\mathrm{Cr}>$ $\mathrm{V}>\mathrm{Ni}>\mathrm{Co}>\mathrm{As}$. Strong correlation was found between these metals ( $\mathrm{Mn}$ and $\mathrm{V}$ in sizes $<75$ and $\geq 150$ ), (As and $\mathrm{Co}$ in size $\geq 150$ ), ( $\mathrm{Ni}$ and $\mathrm{Cr}$ in size $\geq 150$ and $<75)$, respectively. The strong correlation that was found confirmed that their contribution was from anthropogenic sources i.e., industrial activities, storm and urban inflow, agricultural activities and ship reparation that is taking place in and around the harbour.

Acknowledgments: We wish to thank the management of Cape Peninsular University of Technology, Cape Town, South Africa for the URF 2011/2012 research grant offered H. K. Okoro for his doctoral studies. H. K. Okoro also acknowledges University of Ilorin, Ilorin, Nigeria for a supplementation staff development award. Acknowledgement also goes to Mr. Sebastian Brown, Alistair Aldonis and Ashley Davids of CSIR, South Africa for being part of the sampling team.

\section{LITERATURE CITED}

COMBEST, K. B. 1991. Trace metals in sediments: Spatial trends and sorption processes. Water Res. Bull. 27:19-28.

EL-MOSELHY, K. H., M. ABD, AND H. AL-AZIM. 2005. Heavy metals content and grain size of sediments from Suez Bay, Red Sea, Egypt. Egypt. J. Aquat. Res. 31(2), inpress.

EL-MOSELHY, K. M. 2006. Distribution of vanadium in bottom sediments from the marine coastal area of the Egyptian seas. Egyptian J. Aquatic Res. 1687-4285 32(1):12-21.

FATOKI, O. S., H. K. OKORO, F. A. ADEKOLA, B. J. XIMBA, AND R. G. SYNMAN. 2012. Bioaccumulation of Metals in black mussels (Mytillus galloprovincialis) in Cape Town Harbour, South Africa. The Environmentalist 32:48-57. Springer Science + Business Media LLC 2011: DOI 10.1007/ s10669-011-9370-5.

FÖRSTNER, U., W. CALMANO, AND J. SCHOER. 1982. Metals in sediments from the Elbe, Wiser and Ems estuaries and from the German Bight: grain size effects and chemical forms. Thalassia Jugosl. 12:30-36.

GIBBS, R. J. 1977. Transport phases of transition metals in the Amazon and Yukon rivers. Geol. V. 9. Soc. Am. Bull. 88:829-843.

LEONI, L., AND F. SARTORI. 1996. Heavy metals and arsenic in sediments from the continental shelf of the Northern Tyrrhenian/EasternLigurian seas. Mar. Environ. Res. 41(1):73-98.

LIN, J. G., AND S. Y. CHEN. 1998. The relationship between adsorption of heavy metals and organic matter in river sediments. Environment Int. 24:345-352.

MOORE, J. N., E. J. BROOK, AND C. JOHNS. 1989. Grain size partitioning of metals in contamined coarse-grained river floodplain sediment: Clark Fork River, Montana. USA. Environ. Geol. Wat. Sci. 14:107-115.

MULLER, G. 1979. Schwermetalle in densedimenten des RheinsVeranderungenSeit 1971. Umschau. 79(24):778-783.

PEHAIM, J. 2004. Heavy metals in clams and sediments from Morro Bay. M.S. Thesis, Fac. Calif. Polytech State Univ, San Luis Obispo, $46 \mathrm{p}$.

SALOMONS, W., AND U. FÖRSTNER. 1980. Trace metal analysis on polluted sediments: part II: evaluation of environmental impact. Environ. Techn. Letters 1:506-517.

WANG, J., AND C. CHEN. 2006. Biosorption of heavy metals by Saccharomyces cerevisiae: A review. Biotechnol. Advance 24:427-451.

WANG, W. X., AND N. S. FISHER. 1997. Modelling the influence of body size on trace element accumulation in the mussel Mytillus edulis. Mar. Ecol. Prog. Ser. 161, 103-115.

WHITNEY, P. R. 1975. Relationship of manganese-iron oxides and associated heavy metals to grain size in stream sediments. J. Geoch. Explor. 4(2):251-263.

WINDOM, H. L., R. G. SMITH, JR., AND C. RAWLINSON. 1989. Particulate trace metal composition and flux across the south eastern U.S. continental shelf. Mar. Chem. 27:283-297. 